\title{
Microbiological Quality of Asadero Cheese Manufactured with a Plant Based Coagulant from Solanum elaeagnifolium
}

\author{
Nina del Rocío Martínez-Ruiz, Sandra Flores Enriquez, Rosa Emma Vázquez-Nájera, \\ José Alberto López-Díaz \\ Departamento de Ciencias Químico Biológicas, Instituto de Ciencias Biomédicas, Universidad Autónoma de Ciudad Juárez, Ciudad \\ Juárez, México. \\ Email: joslopez@uacj.mx
}

Received March 28 ${ }^{\text {th }}, 2013$; revised April 29 $9^{\text {th }}, 2013$; accepted May $7^{\text {th }}, 2013$

Copyright (C) 2013 Nina del Rocío Martínez-Ruiz et al. This is an open access article distributed under the Creative Commons Attribution License, which permits unrestricted use, distribution, and reproduction in any medium, provided the original work is properly cited.

\begin{abstract}
In Chihuahua, north Mexico, the berries of Solanum elaeagnifolium (trompillo or silverleaf nightshade) have been used in the manufacture of artisanal filata-type asadero cheese. Solanum elaeagnifolium is a wild plant that possesses proteases in its fruit; those enzymes exhibit general proteolytic activities, which are useful in traditional asadero cheesemaking as a rennet substitute. These type of cheese is softer than those made with rennin or chymosin due to their water content and proteolysis. Thus, the aim of this work was to explore microbiological susceptibility of asadero cheese made with an extract from ripe berries and compared with those elaborated with commercial rennet. Crude extract of such fruit was obtained by salting out with ammonium sulfate (40\%). Cheeses were obtained by a standardized process only changing the enzyme, packaged in plastic bag or vacuum bag and storage at $4{ }^{\circ} \mathrm{C}-6^{\circ} \mathrm{C}$. The study included the analysis of spoilage bacteria (total aerobic count, yeasts and molds), indicators of hygiene (total coliforms and E. coli) and fecal contamination (fecal coliforms) after 1, 7, 14, 21 and 28 days of production. Although cheese made with $S$. elaeagnifolium had lower microbial growth, the aerobic count and yeasts and molds count of all cheese samples showing a 28 days shelf life. Total coliforms, in limits beyond the established ones by the Mexican legislation for human consumption with no effect of the enzyme type used for production, as well as for fecal coliforms. Differences were detected just for packaged method, suggesting that good manufacturing practices take place not the plant coagulant.
\end{abstract}

Keywords: Milk Coagulation; Plant Coagulant; Silverleaf Nightshade; Trompillo; Microbiological Quality

\section{Introduction}

In Chihuahua Mexico, asadero cheese is produced and consumed along the state. It is a fresh cheese of stretched curd type, pleasantly tangy white cheese, and production is typically a home-based enterprise. The cheeses with these characteristics, especially stretchability, are members of the pasta filata group and include Mozzarella, Provolone, and Kashkaval [1].

The berry of the Solanum elaeagnifolium Cav (silverleaf nightshade) or so called trompillo in Mexico, is used as a rennet substitute in the production of asadero cheese. Chihuahua's natives use the trompillo as a coagulating enzyme source [2]. S. elaeagnifolium is a deep-rooted, native perennial, which rarely reaches a height of more than 3 feet; leaves are alternate and entire. Leaf margins are normally wavy. Flowers are typical of the nightshade family, potatoes, peppers, and tomatoes [3]. The fruit, initially spherical, green and fleshy, becomes yellow to orange at maturity.

Trompillo is a wild plant that possesses proteases in its berry; those enzymes exhibit general proteolytic activities, which are useful in traditional asadero cheesemaking, reported since about one century [4]. Plant coagulants share biochemical features with chymosin, the enzyme of the rennet. Both, chymosin and plant coagulants cleave the Phe105-Met106 bond of the milk protein $\kappa$-casein, but plant coagulants are more proteolytic and have broader specificity on $\alpha \mathrm{s} 1$ - and $\beta$-caseins than chymosin [5-7]. However, it is possible to obtain cheeses with adequate functional properties with $S$. elaeagni- 
folium berries as an enzyme source. Several authors have reported the use of plant's enzymes (cardosins from Cynaras) in different handmade cheeses and showed that the sensory characteristics of those cheeses are similar or better than cheeses manufactured with commercial rennet [8-10]. Similar cheeses to asadero cheese have a shelf life of $6 \mathrm{wk}$, but usually develops an off-flavor and loses textural integrity by $4 \mathrm{wk}$, potentially due to the lack of salt and high moisture that allow the outgrowth of undesirable bacteria [11].

Cheese is a complex and dynamic microbial ecosystem characterized by the presence of a large variety of bacteria, yeasts, and molds. Some microorganisms, including species of lactobacilli or lactococci, are known to contribute to the organoleptic quality of cheeses, whereas the presence of other microorganisms may lead to spoilage or constitute a health risk [12]. The microbial safety of foods continues to be a major concern to consumers, regulatory agencies and food industries throughout the world. Many food preservation strategies have been used traditionally for the control of microbial spoilage in foods but the contamination of food and spoilage by microorganisms is a problem yet to be controlled adequately. There is no information about effect of S. elaeagnifolium on the microbial safety of asadero cheese. The aim of this work was to explore microbiological susceptibility of asadero cheese made with an extract from ripe berries and compared with those elaborated with commercial rennet.

\section{Materials and Methods}

\subsection{Sample Collection}

Wild trompillo's fruits were obtained from fields in $\mathrm{Cd}$. Juárez, Delicias and Rodrigo M. Quevedo, Chihuahua State, Mexico. Ripe yellow fruits were stored at $-20^{\circ} \mathrm{C}$. Commercial Chymosin (Rennin Laczyme-20, Enmex, Mexico) was used. Bovine milk was supplied by the Department of veterinarian science, Autonomous University of Ciudad Juarez.

\subsection{Enzyme Extract}

The berries of $S$. elaeagnifolium were macerated and homogenized 1:3 with $0.1 \mathrm{M}$ acetate buffer ( $\mathrm{pH} 5.2$ ), $1 \%$ Polyvinylpolypyrrolidone (PVPP) was added to prevent oxidation. Supernatant was recovered at $2000 \times \mathrm{g}$ for 5 $\min$ at $4^{\circ} \mathrm{C}$. Crude extract was obtained from the supernatant by salting out with ammonium sulfate $(40 \%)$, pellet was recovery at $2000 \times \mathrm{g}$ for $5 \mathrm{~min}$ at $4^{\circ} \mathrm{C}$, and solubilized in acetate buffer $\mathrm{pH}$ 5.2, to obtain a protein concentrate extract (CE). Extract's protein was quantified by Bradford method [13] and stored at $-20^{\circ} \mathrm{C}$ until used.

\subsection{Preparation of Cheeses}

Asadero cheeses were obtained by a standardized process, just changing the enzyme source. Fresh milk pasteurized at $63^{\circ} \mathrm{C}$ during $30 \mathrm{~min}$ was acidified by citric acid $(10 \%)$ addition until $34^{\circ} \mathrm{D}$ were reached and warmed to $32^{\circ} \mathrm{C}$. Calcium chloride $(0.02 \%)$, Lactic culture DMS ${ }^{\circledR}$ DelvoTec MT-53X/54Y DSL (Latococcus lactis subsp lactis l, Latococcus lactis subsp cremoris and Streptococcus thermophilus) were incorporated according to the manufacturer's instructions. Commercial rennet (CR) or CE was added at equivalent proportions. Incubation was held at $32^{\circ} \mathrm{C}$ for $40 \mathrm{~min}$. The coagulum formed was cut with a spatula into small cubes of about $1 \mathrm{~cm}^{3}$, and maintained at $35^{\circ} \mathrm{C}$ until milk's whey reached $34^{\circ} \mathrm{D}$. Whey was removed and sodium chloride was added (1.4\%). Curd was melted at $60^{\circ} \mathrm{C}-63^{\circ} \mathrm{C}$ until it formed elastic strands; these were dried at ambient temperature, 15 min each side. The strips were rolled, weighed and divided into samples of $10 \mathrm{~g}$. The samples were packed in both sealable polyethylene bag or in vacuum sealable bag and stored at $4^{\circ} \mathrm{C}-6^{\circ} \mathrm{C}$ until analysis.

\subsection{Evaluation of Manufacture Practices}

Different levels of care in the process were considered because of the implications of the artisanal manufacture of asadero cheese. Cleanup actions were implemented, sanitation and control of pollution sources. Process A, surface cleaning was performed on tables, utensils and equipment, using commercial cleaning agents. The personnel was wearing gown and cap. Process B, the process further A, surfaces were sanitized with a quaternary ammonium solution $200 \mathrm{ppm}$. Staff was wearing gown, cap and gloves. Process C, as well as the process used in $\mathrm{A}$ and $\mathrm{B}$, plus the utensils were immersed in chlorine solution $50 \mathrm{ppm}$ and flamed; aluminum foil was used for draining cheeses. Process D, plus all the practices mentioned above, was denied entry to people to the area of the cheese making, room ventilation was closed, utensils were sterilized during the whole process and staff was wearing gown, cap, gloves and masks [14].

\subsection{Microbiological Analysis}

The milk was analyzed for the total coliforms content, before and after pasteurization. The asadero cheese samples made with $\mathrm{CR}$ or $\mathrm{CE}$, packaged in resealable plastic bags and bags under vacuum were analyzed for spoilage bacteria (total aerobic count, yeasts and molds), indicators of hygiene (total coliforms) and fecal contamination (fecal coliforms), according to standardized procedures of the Bacteriological Analytical Manual [15]. Bacteriological tests were performed on days 1, 7, 14, 21 and 28 storage. Yeast and molds were analyzed until day 28 and 
35. In determining fecal coliform Most Probable Number, a confirmatory test was conducted for the presence of Escherichia coli. The microbiological evaluation results of the two types of cheese were compared using the Student $t$-test $(p<0.05)$ using the statistical program SPSS 15.0 (Statistical Package for Social Sciences, SPSS Inc. Chicago, Ill.).

\section{Results and Discussion}

\subsection{Analysis of Microorganisms in Milk}

The total coliform limit for pasteurized milk should be 10 $\mathrm{CFU} / \mathrm{mL}$ at the production plant and $20 \mathrm{CFU} / \mathrm{mL}$ at the point of sale, as provided by the Mexican legislation [16]. No pasteurized milk from this study was $35,000 \mathrm{CFU} / \mathrm{mL}$ and $<3 \mathrm{CFU} / \mathrm{mL}$ for pasteurized. The counts were conducted in the 1:10 dilution and the value found for total coliforms in pasteurized milk was lower than the limit set in the Mexican standards and are consistent with the results determined by others $[17,18]$. This result is important because it implies that there is no contamination prior to experimental treatments.

\subsection{Manufacture Practices}

The effect of Good Manufacturing Practices (GMP) in total coliform counts for cheese made with $\mathrm{CE}$ and commercial packaging in sealable plastic bag and under vacuum packaging can be seen in Figure 1. The results reflect a decrease of coliforms based on the process used A $>\mathrm{B}>\mathrm{C}>\mathrm{D}$. The set of operations carried out in the process $\mathrm{D}$ proved to be the best in terms of quality healthcare for Asadero cheese making, which is consistent with the statement by related studies $[17,19]$.

The incubation step is the period in which opportunistic microorganisms can grow and affect the final quality of cheese whether appropriate conditions exist. It is necessary to consider the cleaning and disinfection of all equipment used in the processing of cheese or any other food as well as having a HACCP plan [17]; although this is so difficult in the traditional and small cheese plant. An advantage of asadero cheese making is that one of the last stages is carried out at melt temperatures similar to pasteurization, so that this could be a control point if properly done.

\subsection{Total Coliforms Count}

The Figure 2 shows the total coliform counts in cheese made with $\mathrm{CE}$ and $\mathrm{CR}$ packaged in resealable plastic bag. The number of colonies tend to decrease over time in both treatments, without representing a significant difference $(p<0.05)$ between them until day 21 . At day 28, treatment with $\mathrm{CE}$ showed a decrease in the number of

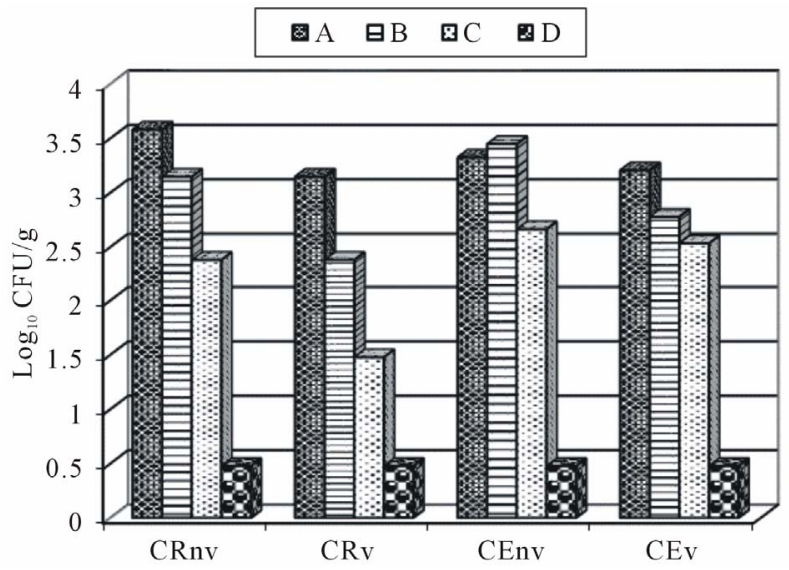

Figure 1. Effect of safe handling in different process of handmade of Asadero Cheese. CRnv, Commercial rennet and plastic bag treatment without vacuum; CRv, Commercial rennet and vacuum bag treatment; $C E n v, S$. elaeagnifolium Concentrate extract and plastic bag treatment without vaCuum; CEv, S. elaeagnifolium Concentrate extract and vacuum bag treatment.

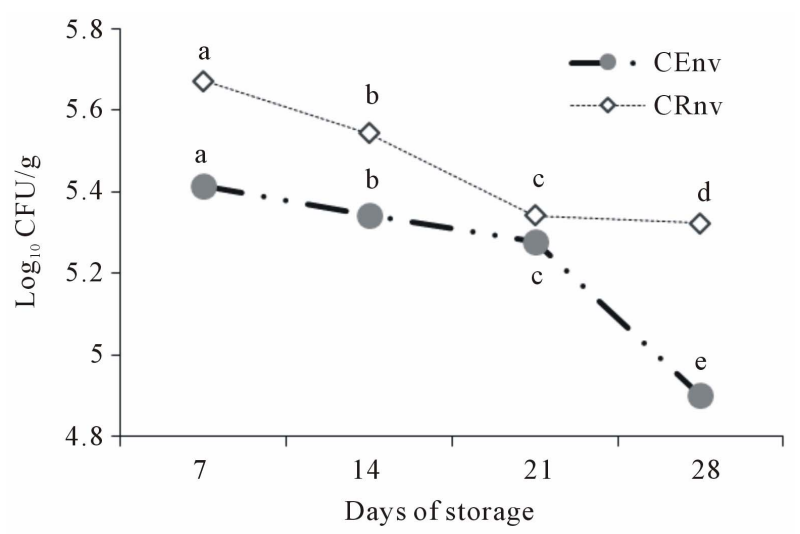

Figure 2. Total coliforms counts in Asadero Cheese during storage. CEnv, S. elaeagnifolium Concentrate extract and plastic bag treatment without vacuum; CRnv, Commercial rennet and plastic bag treatment without vacuum. Different letters represent difference statistically significant $(p<$ 0.05).

coliform colonies $(p<0.05)$, compared with CR cheese. Similar results have been reported in related cheeses during ripening $[11,18,20]$. This behavior is caused by the development of starter cultures, as they at $\mathrm{pH} 4$ and 5 in dairy products inhibit the common and pathogenic flora, achieving lengthen the shelf life of product. Moreover, some studies indicate that the starter culture has a competition for colonization sites and substrates, fermentation products (organic acids, hydrogen peroxide, etc.) inhibitory to many pathogens [21].

Furthermore, it has been shown that lactic bacteria as Lactococcus sp. Lactis, Streptococcus thermophilus and Lactobacillus, and others, produce bacteriocins capable 
of inhibiting both gram positive and gram negative [11, $22,23]$. Therefore, the decreasing growth of total coliforms along Asadero cheese storage may be due to lactic microorganisms development.

\subsection{Effect of Packaging on Fecal Coliform}

The results of cheese with CE packing under vacuum during the different storage days, can be seen in Figure 3. According to the Standard Mexican legislation the maximum limit of fecal coliforms in cheese is $100 \mathrm{CFU} / \mathrm{g}$ [24]. This limit was exceeded on day one of storage, as shown in the graph, but tends to decrease with advancing storage time. The result shows a behavior similar to that developed for total coliforms. From the seventh day of storage, the cheese in both types of packaging decreased fecal coliform count over that obtained on day one, representing count below the limits set by the legislation. This behavior has been reported in similar studies in different cheeses, in addition to the discussed in the previous section, this is attributing to inhibition by the starter cultures due to the substrate competition $[11,21,25]$. This trend is repeated in both packages, presenting a positive effect on vacuum packaging with lower microbial load present. This is because the vacuum packing limits the availability of oxygen. The cheese packed under vacuum was favorable for controlling coliform microorganisms, since lower counts were significantly different $(p<0.05)$ compared with cheese packed in sealable plastic bag, these results are consistent with microbiological studies conducted in different packaged foods [26].

Both cheeses made with $\mathrm{CE}$ and $\mathrm{CR}$ showed no growth of $E$. coli during the storage period. The presence of $E$. coli in foods such as cheese, involves a direct or indirect contamination, reflecting poor hygiene and inadequate process, so that the product can be considered safe.

\subsection{Total Aerobic Count}

The aerobic microorganisms count for cheeses made with the two types of coagulant and packaged in resealable plastic bags are show on Figure 4. The trend for both treatments was increasing the UFC during storage. Both $\mathrm{CE}$ and $\mathrm{CR}$ cheeses had a higher count, especially at 21 and 28 days. These results are considered as a normal process, some authors have found that most of the lactic acid bacteria in cheese, after 15 days of ripening, occupied the most aerobic count and that after a month have dominated the bacterial community [27,28]. This correlate with the lower coliforms count, since has been discussed that lactic acid bacteria growing in raw milk or cheese and tend to give a protective action against a large number of undesirable microorganisms. It should be

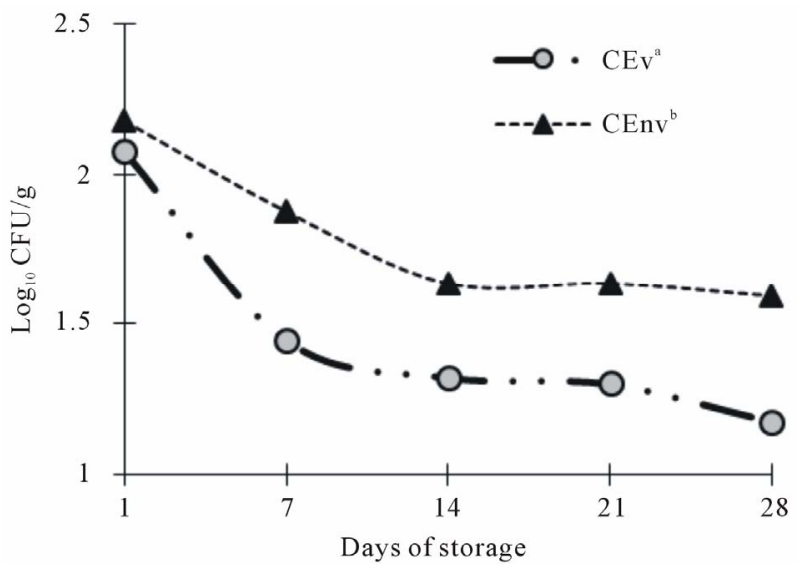

Figure 3. Fecal coliforms in Asadero Cheese handmade with S. elaeagnifolium Concentrate extract, packaging under vacuum (CEv) and no vacuum (CEnv). Different letters represent difference statistically significant $(p<0.05)$.

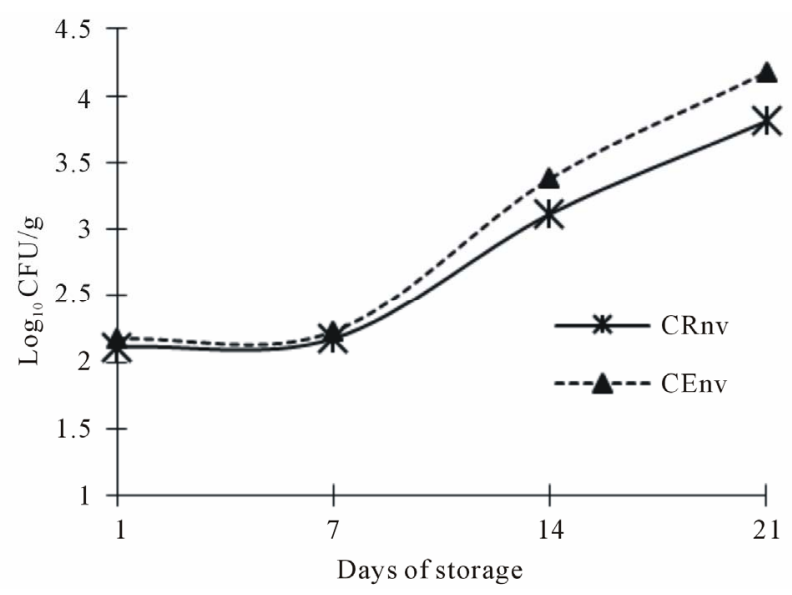

Figure 4. Aerobic mesophilics counts in Asadero Cheese. CRnv, Commercial rennet and plastic bag treatment without vacuum; CEnv, S. elaeagnifolium Concentrate extract and plastic bag treatment without vacuum.

noted that the aerobic mesophilic count is not considered at this point as an indicator of spoilage, this microbial flora is part of the starter culture added (Lactococcus lactis subsp lactis, Lactococcus lactis subsp cremoris and Streptococcus thermophilus). This bacteria show an increasing growth throughout the asadero cheese shelf life and this is desirable for the cheese formation and to add acid flavor and sensory characteristics of the final product $[29,30]$.

\subsection{Yeast and Molds}

The trend of growth of yeast and molds in cheeses made with $\mathrm{CE}$ or $\mathrm{CR}$ is shown in Figure 5. Although the greatest growth observed was on CR cheese, it is within the safe limits allowed by Mexican law, which is 500 $\mathrm{CFU} / \mathrm{g}$ [24]. Cheeses of the two treatments were within 


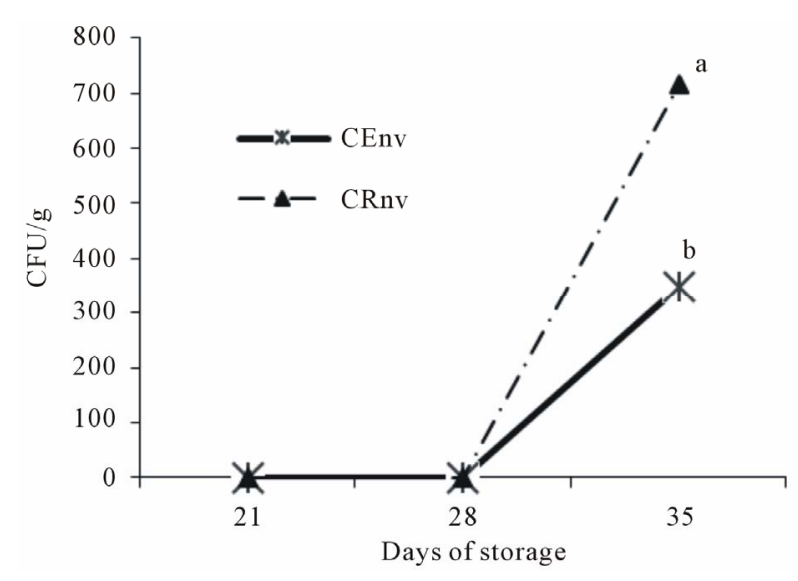

Figure 5. Molds counts in Asadero Cheese. CEnv, S. elaeagnifolium Concentrate extract and plastic bag treatment without vacuum; CRnv, Commercial rennet and plastic bag treatment without vacuum. Different letters represent difference statistically significant $(p<0.05)$.

the limits until 21 and 28 days of storage. CE Cheese still remained within the safe limit established by Mexican law at the day 35, different to the CR treatment that have increased molds, resulting different at 35 days $(p<0.05)$, which probably means that $S$. elaeagnifolium extract may have an anti-mold ability or produce cheese characteristics inappropriate for mold growth at the long term. In some reports with cheese similar to this study it was found that the cheese made from goat milk stored at refrigeration $\left(4^{\circ} \mathrm{C}\right)$ remains unchanged from fresh and microorganism deterioration after 35 days of storage [31, 32]. Yeast and molds in foods often cause impairment, function as health indicators and behave as pathogens through the production of toxins, however in the case of ripened products made with molds, their presence has no a meaning health [12]. The mold on the surface of fresh cheeses suggests early deterioration and lack of freshness. Its microscopic development in food poses a risk in the production of toxic substances to the health of consumers [33]. This kind of microorganisms are most often found in soft cheeses, usually comprising the genera Alternaria, Aspergillus, Cladosporidium, Monilia, Mucor and Penicillium and yeasts Geotrichum candidum and Candida spp. [34,35].

\section{Conclusions}

There were no differences between the two types of coagulants in most microbiological parameters; there are no effects of the plant coagulant $S$. elaeagnifolium on the microbiological quality of asadero cheese during 28 days of shelf life. Coagulant plant tends to inhibit the mold growth until 35 days, however further investigation is recommended. Manipulation of pasteurized milk at room temperature is an important point of post-pasteurization contamination. The contamination with undesirable microorganisms in the incubation step can result in a safety hazard for asadero cheese. The terms of packaging and storage temperature of finished product are also important. Good manufacturing practices remain crucial for obtaining an optimal hygienic quality product. Considering that S. elaeagnifolium (Trompillo) is a weed with substantial distribution in northern Mexico, could be considered as an industrial source of milk coagulant in the manufacture of different cheeses. Before a further application of $S$. elaeagnifolium extract in cheese, the sensory evaluation is recommended. Development of cost effective isolation procedures that yield standardized extracts as well as safety and toxicology evaluation of this coagulant requires a deeper investigation.

\section{REFERENCES}

[1] P. S. Kindstedt, "Moisture Variations in Brine-Salted Pasta Filata Cheese," Journal of AOAC International, Vol. 84, No. 2, 2001, pp. 605-612.

[2] N. Gutierrez-Mendez, D. R. Chavez-Garay and H. Jimenez-Campos, "Exploring the Milk-Clotting Properties of a Plant Coagulant from the Berries of S. elaeagnifolium var. Cavanilles," Journal of food science, Vol. 77, No. 1, 2012, pp. C89-C94. doi:10.1111/j.1750-3841.2011.02468.x

[3] USDA, "Plants Database, U.S. Department of Agriculture, Natural Resources Conservation Service," 2013. http://plants.usda.gov

[4] A. Bodansky, "A Study of a Milk-Coagulating Enzyme of Solanum Elaeagnifolium," Journal of Biological Chemistry, Vol. 61, 1924, pp. 365-375.

[5] J. A. López-Díaz, N. R. Martínez-Ruiz and J. RodrigoGarcía, "Proteolytic Pattern of Asadero Cheese as an Effect of Plant Coagulant and Chymosin," In: G. C. Regalado and A. B. E. García, Ed., Innovations in Food Science and Food Biotechnology in Developing Countries, Asociación Mexicana de Ciencia de los Alimentos, Querétaro, 2010.

[6] Y. H. Low, S. Agboola, J. Zhao and M. Yi Lim, "Clotting and Proteolytic Properties of Plant Coagulants in Regular and Ultrafiltered Bovine Skim Milk," International Dairy Journal, Vol. 16, No. 4, 1996, pp. 335-343. doi:10.1016/j.idairyj.2005.03.013

[7] M. Ramalho-Santos, P. Veríssimo, C. Faro and E. Pires, "Action on Bovine Alpha s1-Casein of Cardosins A and B, Aspartic Proteinases from the Flowers of the Cardoon Cynara cardunculus L.," Biochimica et Biophysica Acta, Vol. 1297, No. 1, 1996, pp. 83-89. doi:10.1016/0167-4838(96)00103-3

[8] N. R. Martínez-Ruiz, J. A. López-Díaz and K. I. Rodríguez-Torres, "Physicochemical Characteristics and Sensory Properties of Asadero Cheese Manufactured with Plant Coagulant from Solanum elaeagnifolium," In: G. C. Regalado and A. B. E. García, Eds., Innovations in Food Science and Food Biotechnology in Developing Countries, Asociación Mexicana de Ciencia de los Alimentos, Que- 
rétaro, 2010.

[9] C. L. C. Esteves, J. A. Lucey, T. Wang and E. M. V. Pires, "Effect of $\mathrm{pH}$ on the Gelation Properties of Skim Milk Gels Made from Plant Coagulants and Chymosin," Journal of Dairy Science, Vol. 86, No. 8, 2003, pp. 2558-2567. doi:10.3168/jds.S0022-0302(03)73850-8

[10] S. V. Silva, A. Pihlanto and F. X. Malcata, "Bioactive Peptides in Ovine and Caprine Cheeselike Systems Prepared with Proteases from Cynara cardunculus," Journal of Dairy Science, Vol. 89, No. 9, 2006, pp. 336-3344. doi:10.3168/jds.S0022-0302(06)72370-0

[11] B. Ganesan, D. A. Irish, C. Brothersen and D. J. McMahon, "Evaluation of Microbial Survival Post-Incidence on Fresh Mozzarella Cheese," Journal of Dairy Science, Vol. 95, No. 12, 2012, pp. 6891-6896. doi:10.3168/jds.2012-5390

[12] M. Duquenne, I. Fleurot, M. Aigle, C. Darrigo, E. Borezee-Durant, S. Derzelle, M. Bouix, V. Deperrois-Lafarge and A. Delacroix-Buchet, "Tool for Quantification of Staphylococcal Enterotoxin Gene Expression in Cheese," Applied and Environmental Microbiology, Vol. 76, No. 5, 2010, pp. 1367-1374. doi:10.1128/AEM.01736-09

[13] M. M. Bradford, "A Rapid and Sensitive Method for the Quantitation of Microgram Quantities of Protein Utilizing the Principle of Protein-Dye Binding," Analytical Biochemistry, Vol. 72, No. 1-2, 1976, pp. 248-254. doi:10.1016/0003-2697(76)90527-3

[14] Codex Alimentarius, "Recommended International Code of Practice. General Principles of Food Hygiene," In Codex Alimentarius, CAC/RCP 1-1969, Rev. 4-2003, pp. 135 .

[15] FDA, "Bacteriological Analytical Manual (BAM), U.S. Food and Drug Administration," 2013.

http://www.fda.gov/Food/FoodScienceResearch/Laborato ryMetods/BacteriologicalAnalyticalManualBAM/ucm2006 949.htm

[16] Ministry of Health (Secretaría de Salud), "NOM-091SSA1-1994. Bienes y Servicios. Leche Pasteurizada de vaca. Disposiciones y especificaciones sanitarias," Dirección General de Control Sanitario de Bienes y Servicios y el Laboratorio Nacional de Salud Pública, México, 1996.

[17] J. Davila, G. Reyes and O. Corzo, "Design of a HACCP Plan for the Gouda-Type Cheesemaking Process in a Milk Processing Plant," Archivos Latinoamericanos de Nutricion, Vol. 56, No. 1, 2006, pp. 60-68.

[18] D. J. D'Amico and C. W. Donnelly, "Microbiological Quality of Raw Milk Used for Small-Scale Artisan Cheese Production in Vermont: Effect of Farm Characteristics and Practices," Journal of Dairy Science, Vol. 93, No. 1, 2010, pp. 134-147. doi:10.3168/jds.2009-2426

[19] R. Zschaler, "Good Manufacturing Practice (GMP) in the food Industry," Zentralblatt fur Bakteriologie, Mikrobiologie und Hygiene, Vol. 187, No. 4-6, 1989, pp. 546556.

[20] R. Alonso, A. Picon, P. Gaya and M. Nunez, "Proteolysis, Lipolysis, Volatile Compounds and Sensory Characteristics of Hispanico Cheeses Made Using Frozen Curd from Raw and Pasteurized Ewe Milk," The Journal of Dairy
Research, Vol. 80, No. 1, 2013, pp. 51-57. doi:10.1017/S0022029912000738

[21] M. Ortigosa, C. Arizcun, A. Irigoyen, M. Oneca and P. Torre, "Effect of Lactobacillus Adjunct Cultures on the Microbiological and Physicochemical Characteristics of Roncal-Type Ewes'-Milk Cheese," Food Microbiology, Vol. 23, No. 6, 2006, pp. 591-598. doi:10.1016/j.fm.2005.09.005

[22] S. Aly, J. Floury, M. Piot, S. Lortal and S. Jeanson, "The Efficacy of Nisin Can Drastically Vary When Produced in Situ in Model Cheeses," Food Microbiology, Vol. 32, No. 1, 2012, pp. 185-190. doi:10.1016/j.fm.2012.06.001

[23] K. Arakawa, Y. Kawai, H. Iioka, M. Tanioka, J. Nishimura, H. Kitazawa, K. Tsurumi and T. Saito, "Effects of Gassericins A and T, Bacteriocins Produced by Lactobacillus gasseri, with Glycine on Custard Cream Preservation," Journal of Dairy Science, Vol. 92, No. 6, 2009, pp. 2365-2372. doi:10.3168/jds.2008-1240

[24] Ministry of Health (Secretaría de Salud), "NOM-121SSA1-1994. Bienes y Servicios. Quesos: Frescos, Madurados y Procesados. Especificaciones Sanitarias," Dirección General de Control Sanitario de Bienes y Servicios y el Laboratorio Nacional de Salud Pública, México, 1996.

[25] P. Sarantinopoulos, G. Kalantzopoulos and E. Tsakalidou, "Effect of Enterococcus faecium on Microbiological, Physicochemical and Sensory Characteristics of Greek Feta Cheese," International Journal of Food Microbiology, Vol. 76, No. 1-2, 2002, pp. 93-105. doi:10.1016/S0168-1605(02)00021-1

[26] Y. Babji and T. R. Murthy, "Effect of Inoculation of Mesophilic Lactic Acid Bacteria on Microbial and Sensory Changes of Minced Goat Meat during Storage under Vacuum and Subsequent Aerobic Storage," Meat Science, Vol. 54, No. 2, 2000, pp. 197-202. doi:10.1016/S0309-1740(99)00101-1

[27] M. J. Torres-Llanez, B. Vallejo-Córdoba, M. E. DíazCinco, M. A. Mazorra-Manzano and A. F. González-Córdova, "Characterization of the Natural Microflora of Artisanal Mexican Fresco Cheese," Food Control, Vol. 17, No. 9, 2006, pp. 683-690. doi:10.1016/j.foodcont.2005.04.004

[28] E. Poznanski, A. Cavazza, F. Cappa and P. S. Cocconcelli, "Indigenous Raw Milk Microbiota Influences the Bacterial Development in Traditional Cheese from an Alpine Natural Park," International Journal of Food Microbiology, Vol. 92, No. 2, 2004, pp. 141-151. doi:10.1016/j.ijfoodmicro.2003.09.006

[29] N. A. Kocaoglu-Vurma, W. J. Harper, M. A. Drake and P. D. Courtney, "Microbiological, Chemical, and Sensory Characteristics of Swiss Cheese Manufactured with Adjunct Lactobacillus Strains Using a Low Cooking Temperature," Journal of Dairy Science, Vol. 91, No. 8, 2008, pp. 2947-2959. doi:10.3168/jds.2007-0592

[30] D. L. Van Hekken, M. A. Drake, F. J. Corral, V. M. Prieto and A. A. Gardea, "Mexican Chihuahua Cheese: Sensory Profiles of Young Cheese," Journal of Dairy Science, Vol. 89, No. 10, 2006, pp. 3729-3738. doi:10.3168/jds.S0022-0302(06)72414-6 
[31] M. Vioque, R. Gomez, E. Sanchez, C. Mata, L. Tejada and J. Fernandez-Salguero, "Chemical and Microbiological Characteristics of Ewes' Milk Cheese Manufactured with Extracts from Flowers of Cynara cardunculus and Cynara humilis as Coagulants," Journal of Agricultural and Food Chemistry, Vol. 48, No. 2, 2000, pp. 451-456. doi:10.1021/jf990326v

[32] Y. W. Park, A. Kalantari and J. F. Frank, "Changes in the Microflora of Commercial Soft Goat Milk Cheese during Refrigerated and Frozen-Storage," Small Ruminant Research, Vol. 53, No. 1, 2004, pp. 61-66. doi:10.1016/j.smallrumres.2003.10.004

[33] A. Rodriguez, M. Rodriguez, M. J. Andrade and J. J. Cordoba, "Development of a Multiplex Real-Time PCR to Quantify Aflatoxin, Ochratoxin A and Patulin Producing Molds in Foods," International Journal of Food Microbiology, Vol. 155, No. 1-2, 2012, pp. 10-18. doi:10.1016/j.ijfoodmicro.2012.01.007

[34] T. M. Cogan and T. P. Beresford, "Microbiology of Hard Cheese," In: R. K. Robinson, Ed., Dairy Microbiology Handbook. The Microbiology of Milk and Milk Products, Wiley-Interscience, New York, 2002.

[35] J. F. Chamba and F. Irlinger, "Secondary and Adjunct Cultures," In: P. F. Fox, P. L. H. McSweeney, T. M. Cogan and T. P. Guinee, Eds., Cheese: Chemistry, Physics and Microbiology, Elsevier Academic Press, USA, 2004. doi:10.1016/S1874-558X(04)80068-X 